\title{
FREQUENCY DISTRIBUTION OF RADIOCARBON DATES AS A TOOL FOR RECONSTRUCTING ENVIRONMENTAL CHANGES
}

\author{
Danuta J Michczyńskal • Adam Michczyński • Anna Pazdur \\ Silesian University of Technology, Institute of Physics, Radiocarbon Laboratory, GADAM Centre of Excellence, \\ Krzywoustego 2, 44-100 Gliwice, Poland.
}

\begin{abstract}
Large sets of radiocarbon dates of 1019 peat, 155 speleothem, and 100 tufa samples, as well as dates of 330 fluvial samples, were investigated in order to estimate environmental variability during the last 16,000 calendar years in Poland. All ${ }^{14} \mathrm{C}$ dating was carried out in the Gliwice Radiocarbon Laboratory, and results are stored in the RoS database. Probability density functions (PDFs) were created by summing up (on the calendar timescale) individual age probability distributions of all dates for different types of material and for different regions of Poland. We used an updated version of the Gliwice Radiocarbon Laboratory calibration program GdCALIB. The ${ }^{14} \mathrm{C}$ dates were calibrated using the IntCal04 calibration curve (Reimer et al. 2004), and results were compared with other paleoenvironmental records. The authors conclude that analyzing PDFs of different types of sediments can be helpful in the qualitative reconstruction of the past environment. The PDF for peat samples primarily reflects paleohydrological conditions; the PDFs for speleothem and tufa samples reflect changes in temperature and humidity, while analysis of the PDF created for fluvial data is in a general agreement with the PDFs constructed for peat samples.
\end{abstract}

\section{INTRODUCTION}

Information about all samples dated in the Gliwice Radiocarbon Laboratory is stored in the RoS database (Piotrowska et al. 2004), which has been in use since the mid-1980s (Pazdur and Porwol 1987; Michczyński and Pazdur 1989, 1994). The development of this database was closely connected with the proposition to create one joint International Radiocarbon Database (IRDB). The prime mover of the efforts to establish the international online database of radiocarbon dates was Renée Kra (Kra 1988; Walker and Kra 1988). Many reasons contributed to the abandonment of the IRDB proposal in the early 1990s. Despite this, many ${ }^{14} \mathrm{C}$ laboratories have their own databases, and some of them make information about the dated samples available on internet sites.

In our opinion, large sets of ${ }^{14} \mathrm{C}$ dates stored in databases are potential sources of information about environmental changes in the past. Using large sets of dates for reconstructing the variability of some events is not a new idea. Since the 1970s, scientists have attempted to obtain paleoenvironmental signals on the basis of large sets of dates (e.g. Geyh and Streif 1970; Geyh 1980; Pazdur et al. 1995; Hercman 2000). By constructing histograms or probability density functions (PDFs) and analyzing the shape of the resulting curves, it is possible to associate periods of time with different environmental conditions. When the criteria for including dates in an analyzed set are chosen suitably (Geyh 1980; Goździk and Pazdur 1987; Stolk et al. 1994), fluctuations in the constructed summed distributions reflect changes in the geological phenomena under investigation. Changes of environmental conditions are reflected in a clustering of dating results in certain time intervals.

\section{METHODS}

The results presented in this paper extend earlier studies (Michczyńska and Pazdur 2004; Michczyński and Michczyńska 2006) in which large sets of ${ }^{14} \mathrm{C}$ dates were used to provide information about environmental changes in the past.

'Corresponding author. Email: Danuta.Michczynska@polsl.pl. 
Dates coming from 1 site (e.g. 1 peat bog) may reflect, first and foremost, local effects. When dates obtained from a larger territory are considered, and PDFs are constructed by adding up particular distributions, the influence of local effects can be eliminated, and information on changes derived from regional or global stimuli are highlighted. We constructed PDFs for different types of material and regions by summing the probability distributions of individual ${ }^{14} \mathrm{C}$ dates after calibration using appropriate normalization procedures. We used an updated version of the Gliwice Radiocarbon Laboratory calibration program GdCALIB (Pazdur and Michczyńska 1989; Aitchison et al. 1989; Michczyńska et al. 1990). The ${ }^{14} \mathrm{C}$ dates were calibrated using the calibration curve IntCal04 (Reimer et al. 2004).

From the outset, we make 2 assumptions (Michczyńska and Pazdur 2004):

1. The amount of organic matter in sediments depends on paleogeographical conditions.

2. The number of ${ }^{14} \mathrm{C}$-dated samples is proportional to the amount of organic matter deposited in sediments in studied time intervals.

During our analysis, we attempt to judge the robustness of these assumptions and to define their limitations. The first assumption is self-evident, whereas the second is equivalent to the assumption of a random character in the collected and dated samples. We have assumed that this random character is preserved because we have large sets of dates coming from a wide geographical area (Poland), and these dates were collected by different investigators interested in various scientific disciplines.

\section{INTERPRETATION PROBLEMS}

Before beginning the analysis of the shape of the constructed probability density functions (PDFs), one should consider what can influence PDFs, apart from changes in environmental conditions:

- The reliability of the constructed PDFs depends on the number of samples in analyzed sets. When the number of dates is too small, the gaps in the PDFs reflect periods when samples have not been collected rather than necessarily indicating a deterioration in environmental conditions. In an earlier publication, we quantified how many dates are required to give statistically reliable results in such analyses (Michczyńska and Pazdur 2004). In that paper, ${ }^{14} \mathrm{C}$ dates were analyzed, and using criteria proposed by Geyh (1980) it was established that the minimum number of dates (statistical fluctuations $<50 \%$ ) depends on the mean standard deviation $(\Delta \mathrm{T})$ and the duration of the analyzed time interval. For example, a time interval of $0-14 \mathrm{kyr}$ and $\Delta \mathrm{T}=115 \mathrm{yr}$, the minimum number of dates is equal to 200 , and for $\Delta \mathrm{T}=120 \mathrm{yr}$ the minimum number is 125 dates. To obtain reliable results (statistical fluctuations $<20 \%$ ), a set of about 780 dates with a mean standard deviation $\Delta \mathrm{T}=115 \mathrm{yr}$ is required.

- Michczyńska and Pazdur (2004) noticed the presence of high, narrow peaks in the PDF constructed on the calendar timescale (cf. Figure 1a), and because of the coincidence of these peaks with the localization of the border of the Holocene subdivision, the authors suggested that the peaks might be a result of the methodology of sampling. The methodology of sampling may also be reflected in an unrealistic bimodality of the PDFs for some time periods. During the analysis of the shape of PDFs, it should be also taken into account that dating the beginning and the end of some phases may produce 2 peaks separated by gaps on the PDF (Starkel et al. 2006). The problem of the presence of these peaks and the influence of the shape of the calibration curve was discussed also by Michczyński and Michczyńska (2006). The authors noticed that the calibration curve is characterized by steep slope sections for time periods where high, narrow peaks of PDFs are observed. Through a Monte Carlo experiment, they found that the shape of the calibration curve influences the shape of the PDF to a considerable degree. The high, nar- 


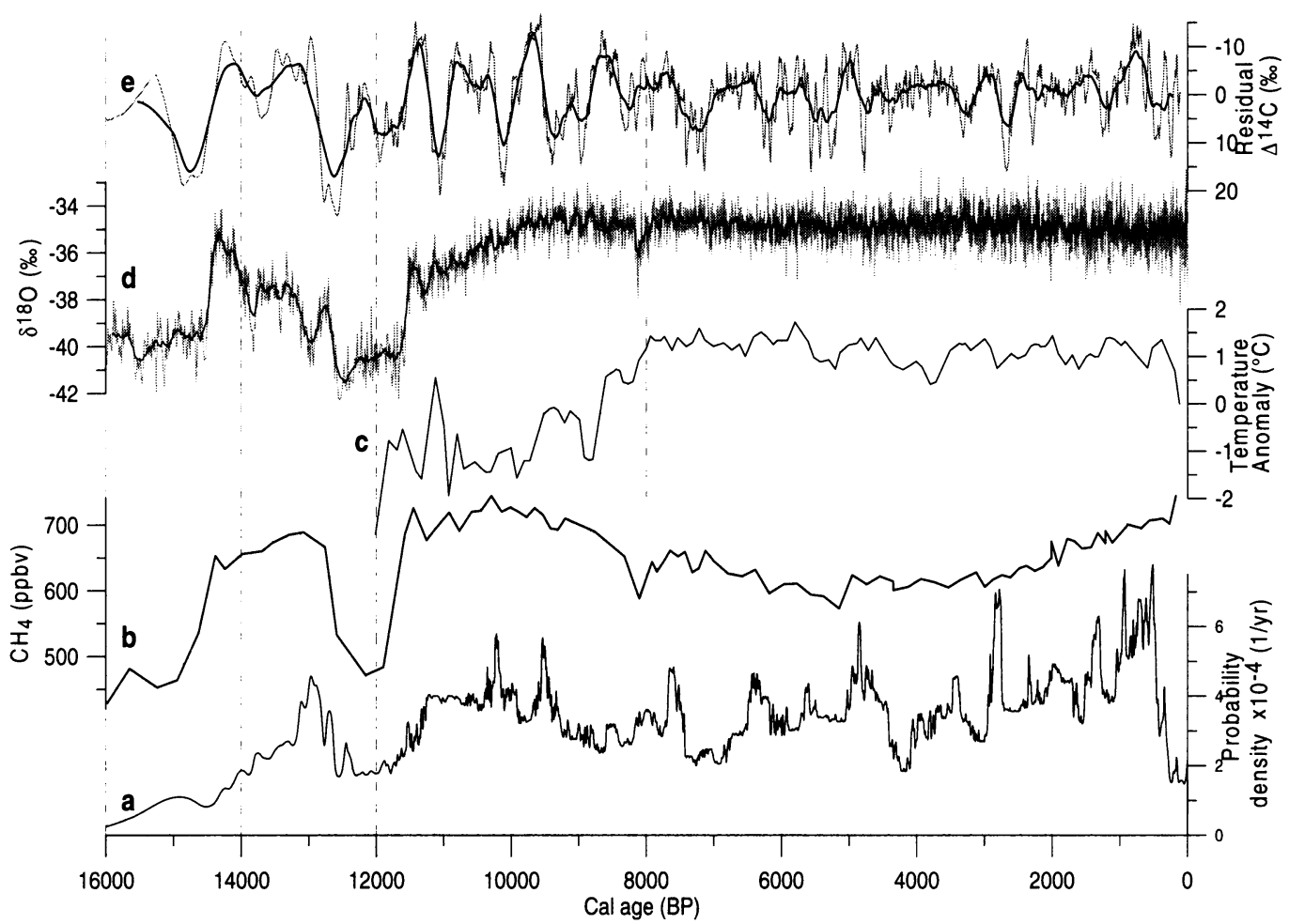

Figure 1 Comparison of the shape of the PDF constructed for $785{ }^{14} \mathrm{C}$ dates for peat samples from the territory of Poland (a) with (b) the variations in atmospheric methane concentration (GRIP ice core, Blunier et al. 1995); (c) the temperature of central Europe during the Holocene reconstructed from pollen data (Davis et al. 2003); (d) the $\delta^{18} \mathrm{O}$ record along the GRIP ice core (Johnsen et al. 1997); and (e) the residual $\Delta^{14} \mathrm{C}$ (Reimer et al. 2004).

row peaks of the PDF are produced both by preferential sampling and through the influence of the calibration curve shape itself. The steep slope sections of the calibration curve work as an amplifier and increase the height of the PDF. The timing of changes in the environment are identified by preferential sampling from places of visible sedimentation changes, but they are also recorded in the shape of the calibration curve. These effects are cumulative.

- The shape of the PDF is also influenced by the fact that younger deposits are generally better preserved and found more frequently than the older ones. This leads to an obvious tendency: the older the samples, the lower the height of the PDF curve. Moreover, older dates are subjected to greater measurement uncertainty due to purely statistical reasons (Goździk and Pazdur 1987; Michczyńska et al. 2003).

With these reservations in mind, we attempted to find environmental signals recorded in PDFs over the last 16,000 calendar yr.

\section{ANALYZED MATERIAL}

Four sets of ${ }^{14} \mathrm{C}$ dates-1019 peat, 155 speleothem (Pazdur et al. 1995, 1999), 100 tufa samples (Pazdur et al. 2002), and 330 fluvial data (Starkel et al. 2006) - were selected from the RoS database. Our analysis is limited to the Holocene and Late Pleistocene because no mires were preserved in Poland prior to the last glaciation, and dates for peat samples cover only the mentioned period. At the beginning, dates of peat samples from the Baltic coastland were grouped in a separate set because 
changes in the Baltic sink range may influence peat deposition, and therefore there may be differences in deposition between the interior of Poland and the Baltic coastland. We constructed PDFs for all of the materials listed above, as well as for peat and fluvial data for different Polish regions.

Michczyńska and Pazdur (2004) constructed PDFs for 785 dates of peat samples covering the period from the Late Glacial/Holocene transition to the present, and analyzed in detail in the transition period. This period was chosen because it is a time of significant change in the environment, and many paleoclimatic records exist for this period. Excellent agreement between the PDF shapes constructed and other environmental records for the Late Glacial/Holocene transition testify to the validity of the basic assumptions of our analysis (Michczyńska and Pazdur 2004).

In this paper, we attempt to broaden our analysis for the Holocene period. The Holocene is much more stable by comparison with the transition period, and amplitudes of potential global environmental changes are significantly lower. For this period, the influence of regional effects becomes more visible. Only one of our data sets (the set of $785{ }^{14} \mathrm{C}$ dates of peat samples described above) has sufficient determinations to provide statistically reliable results using frequency analysis. In the case of the remaining sets, the PDFs may have some gaps resulting from too few dates.

\section{RESULTS}

The probability density function (PDF) constructed using the bulk of the dates (785 dates for peat samples) was compared with global environmental data (Figures 1a-e). The Late Glacial/Holocene transition is very well recorded in the PDF (cf. Figure $1 \mathrm{a}$ with $1 \mathrm{~b}$ and $1 \mathrm{~d}$ for this time period). The methane concentration curve in the GRIP ice core (Figure 1b; Blunier et al. 1995) also has strong correlations (if we do not take into account high, narrow peaks of the PDF, treating them as the result of a preferential sampling). Methane is formed mainly by the decomposition of organic matter in boggy continental areas, and methane concentration changes are an indicator of climate humidity. During the Atlantic optimum (cf. temperature reconstruction in Figure 1c; Davis et al. 2003), the PDF exhibits a decrease. When the shape of the PDF and the $\delta^{18} \mathrm{O}$ record along the GRIP ice core are compared (Figure 1d; Johnsen et al. 1997), it is evident that there is a high similarity only for the transition period. For the Holocene, there are no significant changes in the $\delta^{18} \mathrm{O}$ value, except the event at $8200 \mathrm{BP}$.

The shape of the PDF suggests that a humid, moderate (or moderate, cool) climate supports peat formation, and this is in excellent agreement with the climate of the largest contemporary areas of peat bogs. The PDF reflects environmental conditions favorable for peat sedimentation to an adequate degree.

PDFs were constructed for all of the types of materials listed above (Figures $2 \mathrm{a}-\mathrm{d}$ ). It is well known that the sedimentation of these materials depends on hydrological conditions. The dry periods are wholly unfavorable for them. By comparing the shapes of PDFs and looking for common time periods characterized by minima, it is possible to establish the periods that were characterized by dry conditions (Figure 2e). These dry periods are very well correlated with those established by RalskaJasiewiczowa (1989) (Figure 2f).

The PDF derived from tufa samples shows a maximum during the Atlantic optimum. The PDF for speleothem dates exhibits a small maximum for this time period as well. Processes of tufa and speleothem formation are more sensitive to temperature changes than processes of peat formation, but they are all very sensitive to dry conditions.

PDFs constructed for peat samples for different Polish regions (cf. Figure 3) and for fluvial data for different parts of Vistula and Oder catchments are presented in Figure 4. There is a very good cor- 


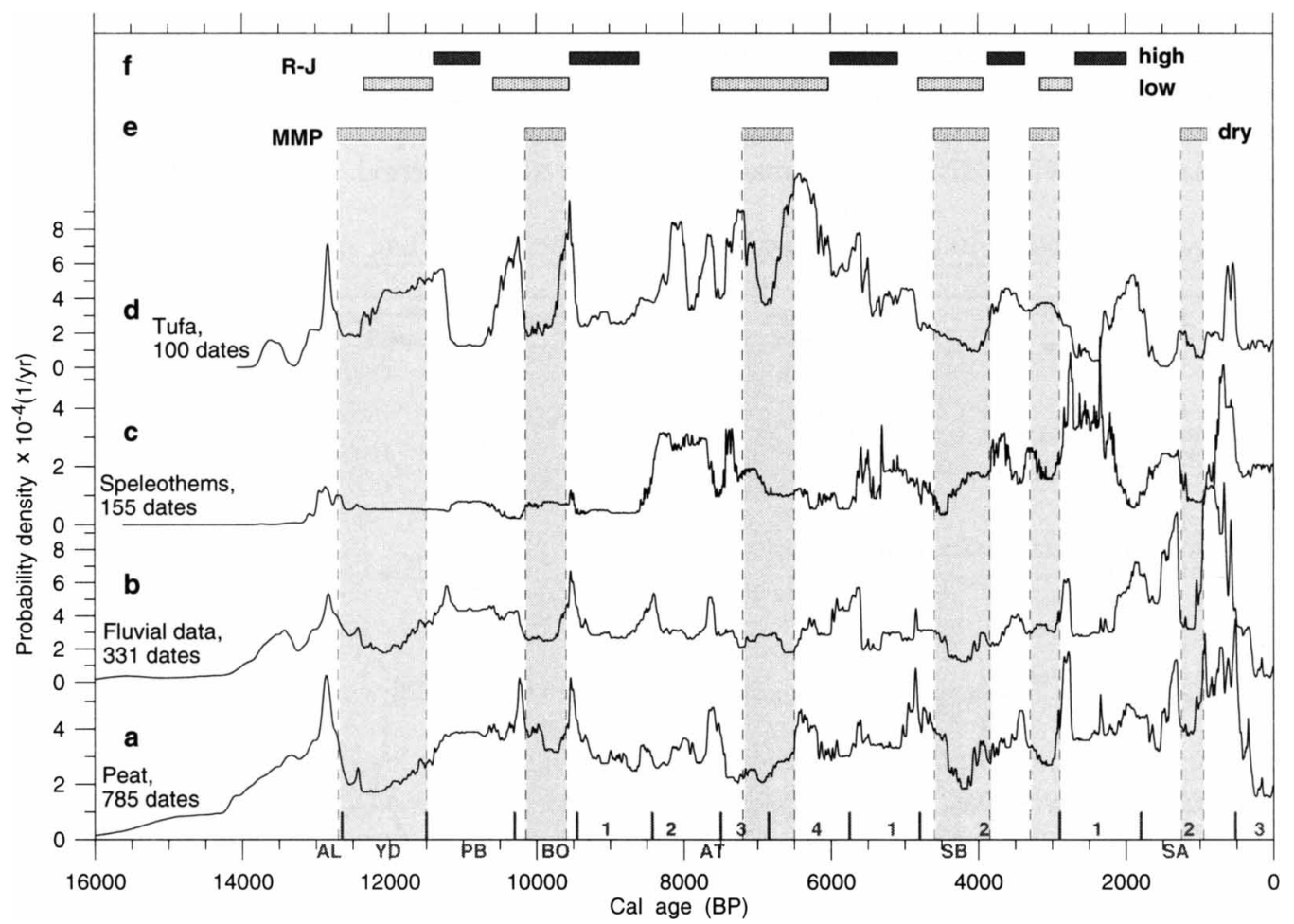

Figure 2 PDFs constructed for sets of ${ }^{14} \mathrm{C}$ dates: (a) 785 dates of peat samples; (b) 331 dates of samples connected with fluvial events; (c) 155 dates of speleothems; (d) 100 dates of tufa samples. Periods with environmental conditions unfavorable for sedimentation (MMP) of all types of analyzed materials; dry periods (e) were established on the basis of coincidence of lowering of PDFs. For comparison, the reconstruction of lakes and mire levels for northern Poland R-J (Ralska-Jasiewiczowa 1989, after calibration) is presented in (f). A good agreement of establishing dry periods is seen. Small vertical lines at the bottom of the figure indicate borders of the Late Glacial and Holocene subdivisions (Pazdur 2004; Starkel et al. 2006).

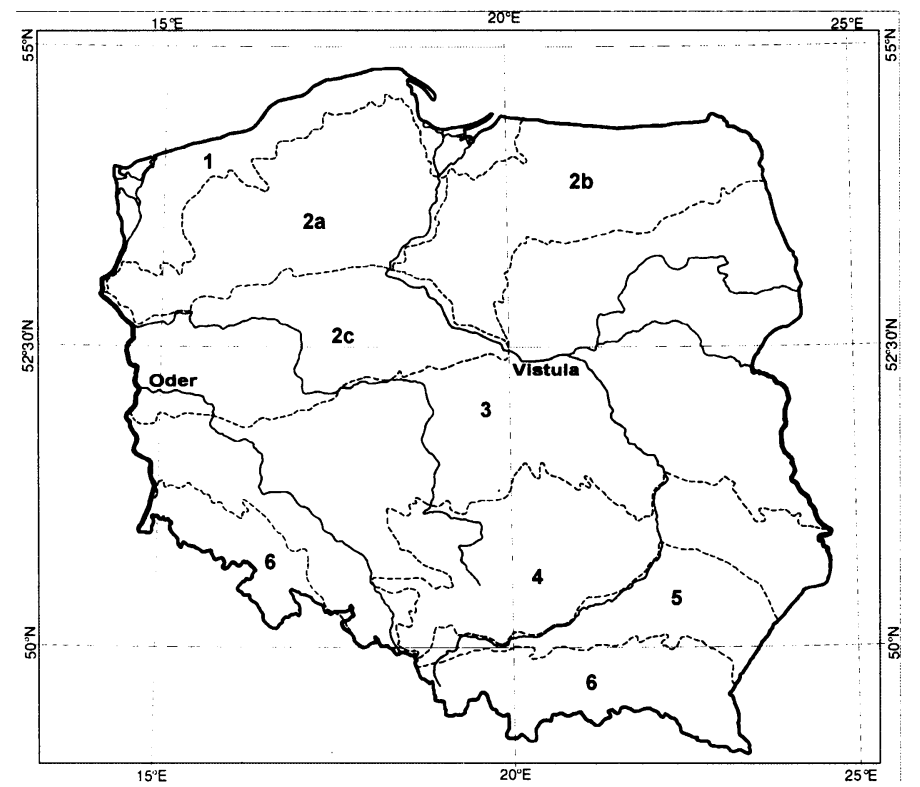

Figure 3 Map of Poland with division on geographical regions: $1-$ Baltic coastland; 2-Lake Districts: a-Pomeranian, b-Mazurian, cGreat Poland; 3-Lowlands; 4Uplands; 5-Subcarpathian Dales; 6-Mountains. The main Polish rivers are also included. 
relation of PDFs for peat samples and fluvial data for all of Poland (except the Baltic coastland) and for separate regions (Figures $4 \mathrm{a}-\mathrm{g}$ ). The different shape of the Baltic PDF peat samples (Figure $4 \mathrm{~h}$ ) is probably the result of the influence of the Scandinavian ice sheet and the Baltic basin. The transition between the Allerød/Younger Dryas is not visible in the PDF shape for this region, and only this region has a PDF with a distinct, wide maximum for the Atlantic period.

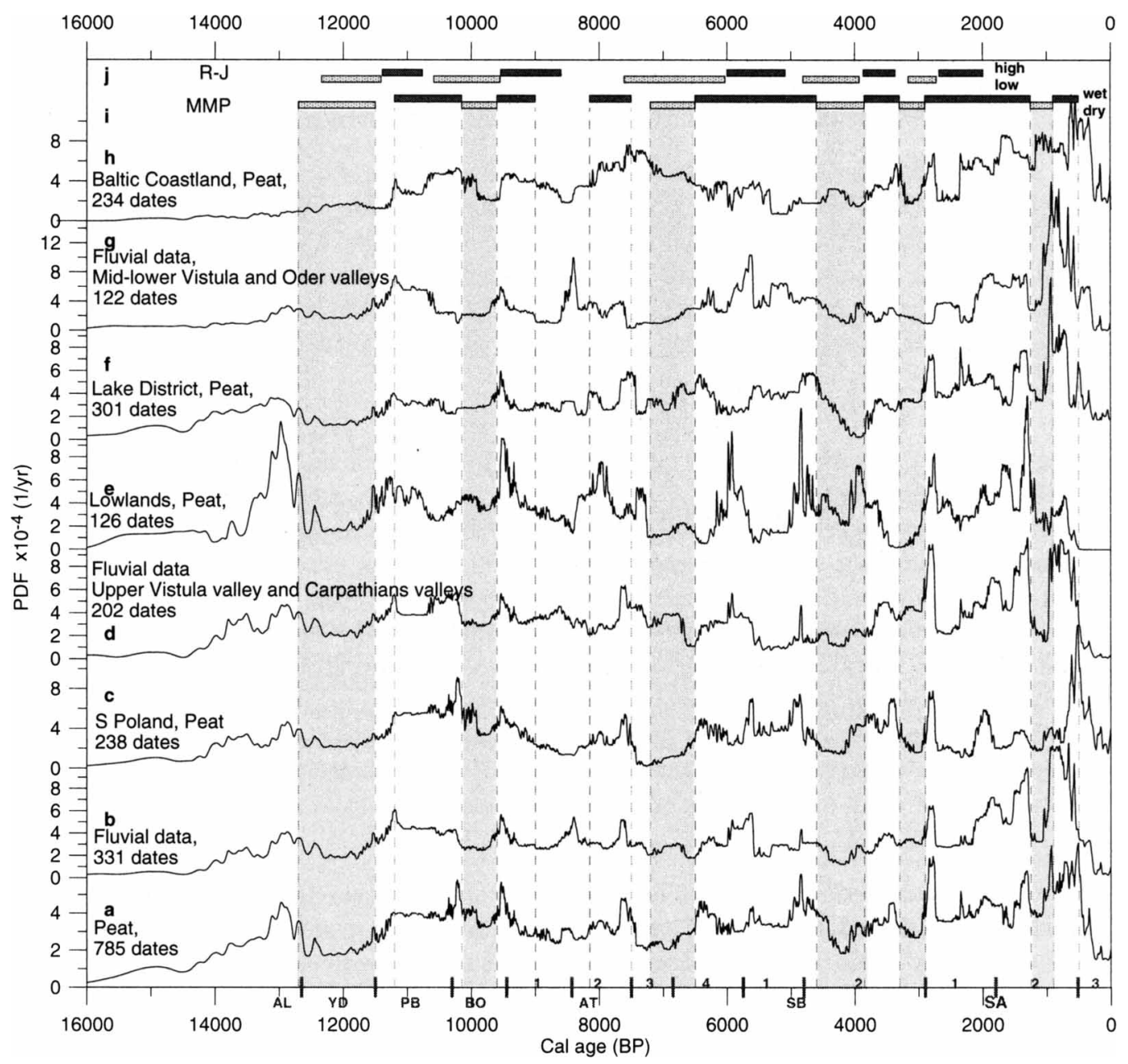

Figure 4 PDFs constructed for sets of ${ }^{14} \mathrm{C}$ dates for different regions of Poland: (a) 785 dates for peat samples, all of Poland; (b) 331 dates for samples connected with fluvial events, all of Poland; (c) 238 dates for peat samples, S Poland (Mountain, Subcarpathian Dales, Uplands; cf. Figure 3); (d) 202 dates for fluvial samples, upper Vistula Valley and Carpathian valleys in Vistula catchments; (e) 126 dates for peat samples, Lowlands; (f) 301 dates for peat samples, Lake Districts; (g) 122 dates for fluvial samples, mid-lower Vistula and Oder valleys; (h) 234 dates for peat samples, Baltic coastland; (i) MMP - evaluation of dry and wet periods on the base of PDFs shapes; (j) R-J - the reconstruction of lakes and mires levels for northern Poland (Ralska-Jasiewiczowa 1989; after calibration). Very good correlation of PDFs in a-g is visible. (i) Estimation of dry and wet periods based on the PDFs' shapes; (j) small vertical lines at the bottom of the figure-the same as in Figure 2.

The distinct tendency to collect samples from selected horizons is reflected in the shape of PDFs for the less numerous sets of ${ }^{14} \mathrm{C}$ dates. The clustering of the dates near the Holocene subdivision borders is visible especially for the sets of $100{ }^{14} \mathrm{C}$ tufa dates (Figure $2 \mathrm{~d}$ ) and for $126{ }^{14} \mathrm{C}$ dates of peat samples coming from the Lowlands (Figure 4e). 
Hydrological conditions during sedimentation play a crucial role for all analyzed types of materials. These hydrological conditions are reflected in the shape of the PDFs. On the basis of the coincidence between gaps and maximums observed in the PDFs for different types of materials and different regions, we estimated several periods of favorable (wet) and unfavorable (dry) conditions in the study area (Table 1).

Table 1 Dry and wet periods established for the territory of Poland.

\begin{tabular}{lc}
\hline Dry & Wet \\
\hline $12,700-11,500$ & $11,200-10,150$ \\
$10,150-9600$ & $9600-9000$ \\
$7200-6500$ & $8150-7500$ \\
$4600-3850$ & $6500-4600$ \\
$3300-2900$ & $3850-3000$ \\
$1250-900$ & $2900-1250$ \\
& $900-500$ \\
\hline
\end{tabular}

\section{CONCLUSIONS}

The following points suggest that the basic assumptions listed above hold true:

- The information about the Late Glacial/Holocene transition is very well recorded in all the analyzed PDFs. A good correlation between all PDFs and other independent environmental data is evident for this time period.

- A very good correlation is observed between the main trend of the methane concentration curve and the shape of the PDF for peat samples for the entire period.

- Paleohydrogeological conditions attested to by the PDFs are very well correlated with those established primarily on the basis of the levels of lakes and mires for northern Poland by Ralska-Jasiewiczowa (1989).

The analysis of PDFs of different types of sediments can be helpful in the qualitative reconstruction of past environments. The main tendency of PDFs reflects environmental conditions favorable and unfavorable for sedimentation to an adequate degree. Analysis of the shape of PDFs can be also helpful in the reconstruction of environmental differences between various regions. For example, the influence of the Scandinavian ice sheet during the transition from Late Glacial/Holocene is very well recorded in the PDF shape for the Baltic coastland region.

The PDFs for peat samples and for fluvial data primarily reflect paleohydrological conditions. PDFs constructed for speleothem and tufa samples reflect changes in temperature and humidity. Common signals (correlation of the gaps and maximums) over all analyzed sets were used for reconstructing hydrological conditions during the Late Glacial and Holocene (Table 1).

The tendency to collect samples from selected horizons is reflected in the shape of PDFs by high, narrow peaks. The clustering of the dates near the Holocene subdivision borders is visible especially for the less numerous sets of ${ }^{14} \mathrm{C}$ dates: sets of $100{ }^{14} \mathrm{C}$ tufa dates (Figure $2 \mathrm{~d}$ ) and for $126{ }^{14} \mathrm{C}$ dates of peat samples coming from Lowlands (Figure 4e). On the other hand, the specific shape of these disturbances (high, narrow peaks) allows us to isolate them from the rest of the environmental signal.

\section{ACKNOWLEDGMENTS}

This research is supported by the Silesian University of Technology research project BW-437/RMF$1 / 2006$. 


\section{REFERENCES}

Aitchison TC, Leese M, Michczyńska DJ, Mook WG, Otlet RL, Ottaway BS, Pazdur MF, van der Plicht J, Reimer PJ, Robinson SW, Scott EM, Stuiver M, Weninger B. 1989. A comparison of methods used for calibration of radiocarbon dates. Radiocarbon 31(3):846-64.

Blunier T, Chappellaz J, Schwander J, Stauffer B, Raynaud D. 1995. Variations in atmospheric methane concentration during the Holocene epoch. Nature 374(6517):46-9.

Davis BAS, Brewer S, Stevenson AC, Guiot J, data contributors. 2003. The temperature of Europe during the Holocene reconstructed from pollen data. Quaternary Science Reviews 22(15-17):1701-16.

Geyh MA. 1980. Holocene sea-level history: case study of the statistical evaluation of ${ }^{14} \mathrm{C}$ dates. Radiocarbon 22(3):695-704.

Geyh MA, Streif H. 1970. Studies on coastal movements and sea-level changes by means of the statistical evaluations of ${ }^{14} \mathrm{C}$-data. Proceedings of the "Symposium on Coastal Geodesy." Münich, 20-24 July 1970. p 599-611.

Goździk J, Pazdur MF. 1987. Frequency distribution of ${ }^{14} \mathrm{C}$ dates from Poland in the time interval $12-45 \mathrm{kyr}$ BP and its palaeogeographical implications. Zeszyty Naukowe Politechniki Śląskiej, s. MatematykaFizyka, z. 56. Geochronometria 4:27-42.

Hercman H. 2000. Reconstruction of paleoclimatic changes in Central Europe between 10 and 200 thousand years BP, based on analysis of growth frequency of speleothems. Studia Quaternaria 17:35-70.

Johnsen SJ, Clausen HB, Dansgaard W, Gundestrup NS, Hammer CU, Andersen U, Andersen KK, Hvidberg CS, Dahl-Jensen D, Steffensen JP, Shoji H, Sveinbjörnsdóttir ÁE, White JWC, Jouzel J, Fisher D. 1997. The $\delta^{18} \mathrm{O}$ record along the Greenland Ice Core Project deep ice core and the problem of possible Eemian climatic instability. Journal of Geophysical Research 102(C12):26,397-410.

Kra R. 1988. The first American workshop on the International Radiocarbon Data Base. Radiocarbon 30(2): 259-60.

Michczyńska DJ, Pazdur A. 2004. Shape analysis of cumulative probability density function of radiocarbon dates set in the study of climate change in Late Glacial and Holocene. Radiocarbon 46(2):733-44.

Michczyńska DJ, Pazdur MF, Walanus A. 1990. Bayesian approach to probabilistic calibration of radiocarbon dates. PACT 29:69-79.

Michczyńska DJ, Michczyński A, Pazdur A, Żurek S. 2003. ${ }^{14} \mathrm{C}$ dates of peat for reconstruction of environmental changes in the past. Geochronometria 22:4754.

Michczyński A, Michczyńska DJ. 2006. The effect of PDF peaks' height increase during calibration of radiocarbon date sets. Geochronometria 25:1-4.

Michczyński A, Pazdur MF. 1989. Local microcomputer database for radiocarbon dates. Zeszyty Naukowe Po- litechniki Śląskiej, Seria: Matematyka-Fizyka, z. 61. Geochronometria 6:27-35.

Michczyński A, Pazdur MF. 1994. Gliwice radiocarbon data bank-present status. Zeszyty Naukowe Politechniki Śląskiej, Seria: Matematyka-Fizyka, z. 71. Geochronometria 10:47-59.

Pazdur A. 2004. Archaeological cultures on the background of climatic changes in the Holocene, Poland. In: Scott EM, Alekseev A Yu, Zaitseva G, editors. Impact of the Environment on Human Migration in Eurasia. NATO Science Series, IV. Earth and Environmental Sciences, Volume 42. Amsterdam: Kluwer Academic Publishers. p 309-21.

Pazdur MF, Michczyńska DJ. 1989. Improvement of the procedure for probabilistic calibration of radiocarbon dates. Radiocarbon 31(3):824-32.

Pazdur MF, Porwoł M. 1987. Microcomputer database system for radiocarbon dates: a pilot project. Zeszyty Naukowe Politechniki Śląskiej, Seria: MatematykaFizyka, z. 56. Geochronometria 4:19-25.

Pazdur A, Pazdur MF, Pawlyta J, Górny A, Olszewski M. 1995. Paleoclimatic implications of radiocarbon dating of speleothems from the Cracow-Wielun Upland, southern Poland. Radiocarbon 37(2):103-10.

Pazdur A, Goslar T, Pawlyta M, Hercman H, Gradziński M. 1999. Variations of isotopic composition of carbon in the karst environment from southern Poland, present and past. Radiocarbon 41(1):81-97.

Pazdur A, Dobrowolski R, Durakiewicz T, Mohanti M, Piotrowska N, Das S. 2002. Radiocarbon time scale for deposition of Holocene calcareous tufa from Poland and India (Orissa). Geochronometria 21:85-96.

Piotrowska N, Szczepanek M, Pazdur A, Zajadacz W. 2004. RoS - a new database system in the Gliwice Radiocarbon Laboratory. Geochronometria 23:51-7.

Ralska-Jasiewiczowa M. 1989. Environmental changes recorded in lakes and mires of Poland during the last 13,000 years. Acta Palaeobotanica 29:1-120.

Reimer PJ, Baillie MGL, Bard E, Bayliss A, Beck JW, Bertrand CJH, Blackwell PG, Buck CE, Burr GS, Cutler KB, Damon PE, Edwards RL, Fairbanks RG, Friedrich M, Guilderson TP, Hogg AG, Hughen KA, Kromer B, McCormac G, Manning S, Bronk Ramsey C, Reimer RW, Remmele S, Southon JR, Stuiver M, Talamo S, Taylor FW, van der Plicht J, Weyhenmeyer CE. 2004. IntCal04 terrestrial radiocarbon age calibration, 0-26 cal kyr BP. Radiocarbon 46(3):1029-58.

Starkel L, Soja R, Michczyńska DJ. 2006. Past hydrological events reflected in Holocene history of Polish rivers. CATENA 66(1-2):24-33.

Stolk A, Törnqvist TE, Hekhuis KPV, Berendsen HJA, van der Plicht J. 1994. Calibration of ${ }^{14} \mathrm{C}$ histograms: a comparison of methods. Radiocarbon 36(1):1-10.

Walker AJ, Kra R. 1988. Report on the International Radiocarbon Data Base (IRDB) Workshop, Archaeology and ${ }^{14} \mathrm{C}$ Conference, Groningen, the Netherlands. $R a$ diocarbon 30(2):255-8. 